\title{
Decellularised Bovine Pericardium for Hernioplasty in Dogs
}

\author{
B. M. Nijin Jos*, C. B. Devanand, K. D. John Martin and Syam K. Venugopal \\ Department of Veterinary Surgery and Radiology, College of Veterinary and Animal Sciences, \\ Mannuthy, Thrissur \\ Kerala Veterinary and Animal Sciences University, India \\ *Corresponding author
}

\section{A B S T R A C T}

\begin{tabular}{l} 
K e y w o r d s \\
$\begin{array}{l}\text { Decellularised } \\
\text { Bovine } \\
\text { pericardium, } \\
\text { Hernioplasty }\end{array}$ \\
Article Info \\
$\begin{array}{l}\text { Accepted: } \\
\text { 10 July 2020 } \\
\text { Available Online: } \\
10 \text { August } 2020\end{array}$ \\
\hline
\end{tabular}

The study was conducted to evaluate the efficacy of decellularised bovine pericardium for hernioplasty in dogs. Six clinical cases of dogs irrespective of age, sex, breed and having hernia on the ventral abdomen presented to the Teaching Veterinary Clinical Complex, Mannuthy and University Veterinary Hospital, Kokkalai were selected for the study. The dogs that were included in the study underwent a detailed general and clinical examination to confirm the location and nature of hernia. Physiological, haematological and biochemical examination was done pre-operatively to assess the patient for undergoing surgery. The treatment plan adopted following the diagnosis of hernia was to correct the hernia by hernioplasty using decellularised bovine pericardium. The surgical correction was performed under general anaesthesia. Under general anaesthesia, the hernial contents were reduced and the decellularised bovine pericardium trimmed to the size of the defect, was sutured to the margins in simple interrupted pattern as an inlay graft. Detailed general, clinical, haematological and biochemical evaluation was performed pre-operatively on day zero and post-operatively on $7^{\text {th }}, 14^{\text {th }}, 30^{\text {th }}$ and $60^{\text {th }}$ day. Clinical examination revealed progression of complete healing in five out of six dogs during the observation period. The tissue changes observed at the surgical site by $7^{\text {th }}$ day post-operative period were oedema, pain and warmth. Complications like formation of seroma at the surgical site, delayed wound healing and recurrence of hernia were observed during the observation period. Result of the study concluded that decellularised bovine pericardium could be used as a biological substitute for the correction of hernia in clinical conditions. Although variations in the haematological and biochemical parameters were noticed during the observation period all were within the normal range. The observations suggested that the implantation of decellularised bovine pericardium did result in any physiological disturbances and proved its efficacy in correcting the hernia as biological substitute in clinical conditions.

\section{Introduction}

Animals were a part of human life for over centuries and rearing them as pets has increased the importance to the extent that many human lives even depend upon them. With the increasing importance of companion animals in human life, their health care currently extends from a basic health checkup up to major surgeries to keep the pet 
animals in perfect condition. Of the surgeries performed in animals, majority is constituted by soft tissue which includes reconstructive surgery, surgery involving gastrointestinal tract, genito-urinary system, cardiothoracic surgery, cosmetic surgery etc.

Among the soft tissue affections, hernia is commonly encountered as congenital or acquired condition in dogs where reconstructive procedures are employed. The incidence of congenital hernia is presently seen at a higher rate and this is mainly occurring as a result of high degree of inbreeding. The acquired cases are more commonly seen as a result of trauma from road traffic accidents (Thilagar et al., 2006). The treatments for the correction of hernias involve both invasive and non-invasive techniques. Non-invasive techniques like application of hernial clamps, tight bandages etc. were usually adopted for congenital condition. As the efficacy of non-invasive techniques is not reliable, selection of invasive techniques is the choice. The most commonly adopted invasive technique for the correction of hernia was herniorrhaphy but for the successful treatment of hernia a tension free correction is adequate. In case of large hernias and in those regions where excessive tension is expected following surgery, herniorrhaphy failed to provide a tension free correction leading to the recurrence of condition (Singh et al., 2011). Hence with the sole aim of providing a tension free correction, hernioplasty techniques were developed utilizing prosthetic meshes.

Synthetic prosthetic meshes were popularly in use for hernioplasty due to ease of availability and low cost. The use of the synthetic meshes, however became compromised in situations like contaminated fields, pre-irradiated tissues etc. due to higher recurrence rate and development of adhesion. In order to overcome their disadvantages autologous grafts were the choice and in large defects it was difficult to obtain sufficient amount of autologous graft material to correct the defect and also procuring the graft would result in significant donor site morbidity (Holton et al., 2005).The occurrence of such disadvantages prompted for the development of alternatives for reconstructive procedures.

The biologic meshes were brought to lime light due to their ability to resist infection, form minimum adhesion with the underlying viscera and hasten the remodeling of the host tissue. Over the years many researches have been performed to evolve an ideal scaffold. Different types of biological meshes have been developed from different sources with the aim of the production of an ideal prosthetic. Bovine pericardium is one such biological mesh that was developed with advantages of infection resistant, minimal tissue reaction and promotes tissue regeneration (D'Ambra et al., 2012). Experimental studies using decellularised bovine pericardium in rats showed that it could successfully induce regeneration following implantation in surgically created hernia (Suvaneeth, 2013). Hence the present study is undertaken for clinical evaluation of the efficacy of decellularised bovine pericardium as a biological tissue substitute for hernioplasty in dogs.

\section{Materials and Methods}

The surgical correction of the hernia was performed by hernioplasty with Decellularised Bovine Pericardium under general anaesthesia.

\section{Pre-operative preparation of patient}

The animals were prepared for surgery by withholding solid food for 12 hours and water for 6 hours prior to surgery. Injection of ceftriaxone sodium was administered 
intravenously at a dose rate of $20 \mathrm{mg} / \mathrm{kg}$ body weight prior to the administration of preanaesthetic medication.

\section{Preparation of graft}

The Decellularised Bovine Pericardium (supplied by Sree Chitra Tirunal Institute of Medical Sciences and Technology, Thiruvananthapuram) was rinsed with sterile normal saline for $15 \mathrm{~min}$ to remove the sterilant used for preserving the graft. The washing was done in three cycles with 5 minute duration and kept ready for hernioplasty (Plate 1).

\section{Anaesthesia}

As preanaesthetic medication dogs were given atropine sulphate at a dose rate of $0.045 \mathrm{mg} / \mathrm{kg}$ body weight as intramuscular injection. After five minutes, xylazine hydrochloride was administered at a dose rate of $1.5 \mathrm{mg} / \mathrm{kg}$ body weight as intramuscular injection. General anaesthesia was induced by administering ketamine hydrochloride ${ }^{3}$ after 15 minutes at a dose rate of $5 \mathrm{mg} / \mathrm{kg}$ body weight as intramuscular injection. The general anaesthesia was maintained by administering equivolume mixture of xylazine hydrochloride and ketamine hydrochloride and diazepam at a dose rate of $0.2 \mathrm{mg} / \mathrm{kg}$ body weight intravenously 'to effect'.

\section{Preparation of site}

The skin over the swelling was prepared for aseptic surgery by shaving and scrubbing with chlorhexidine lotion and washing thoroughly with plenty of water. The surgical site was then mopped dry and painted with Tr. Iodine (Plate 2).

\section{Surgical procedure}

The animal was positioned in dorsal recumbency on the table and drapes were fixed around the hernial swelling. A linear incision extending along the entire length of the swelling was made on the skin to expose the hernia sac. The hernial sac was opened to expose the hernial contents and examined for any adhesions, and if present it was relieved gently before reduction of contents back to the abdominal cavity.

The hernial ring was examined to assess the size of graft material to be used as inlay graft (Devarathnum et al., 2012; Gangwar et al., 2012). The sheet of decellularised bovine pericardium prepared for hernioplasty was trimmed to the required size for covering the hernial defect. The graft was then placed in the defect and sutured to the margins using 10 polyglactin 910 in simple interrupted pattern (Plate 3). The subcutaneous tissue was sutured with 1-0 polyglactin 910 in continuous subcuticular pattern. Skin was apposed with monofilament nylon in horizontal mattress pattern. A gauze stent was fixed over the suture line and applied Tr. Benzoin.

\section{Control of self-mutilation and contamination}

The surgical site was protected from contamination and self-mutilation by applying multi-tailed abdominal bandage (Plate 4).

\section{Post-operative medication}

The dogs were maintained under oral antibiotics post-operatively by administering cephalexin at a dose rate of $20 \mathrm{mg} / \mathrm{kg}$ body weight orally twice daily for five days postoperative. A multi-vitamin syrup was also administered orally one teaspoon twice daily in addition to antibiotics

\section{Removal of skin sutures}

The skin sutures were removed $14^{\text {th }}$ day post operative. 


\section{Evaluation of study}

The study was evaluated by general, clinical, haematological and biochemical examination pre-operatively on day zero and postoperatively on $7^{\text {th }}, 14^{\text {th }}, 30^{\text {th }}$ and $60^{\text {th }}$ of the observation period.

\section{Tissue changes}

The tissue changes at the site of surgery were recorded post-operatively on $7^{\text {th }}, 14^{\text {th }}, 30^{\text {th }}$, and $60^{\text {th }}$ day of the observation period. The complications occurring if any, were noted post-operatively on $7^{\text {th }}, 14^{\text {th }}, 30^{\text {th }}$ and $60^{\text {th }}$ day of the observation period.

\section{Statistical analysis}

The data collected were statistically analyzed with repeated measures ANOVA (Kaps and Lamberson, 2009)

\section{Result and Discussion}

\section{Evaluation of technique}

\section{Anaesthesia}

Anaesthetic regimen followed for the correction of the hernia was satisfactory for the complete procedure.

\section{Surgical technique}

The surgical technique consisted of reducing the herniated contents followed by placing and fixing decellularised bovine pericardium as inlay graft which was trimmed to the size of the defect. The size of the hernial ring was $2 \times 2 \mathrm{~cm}$ in Dog $1,4 \times 5 \mathrm{~cm}$ in Dog 2, $2.5 \times 1.5 \mathrm{~cm}$ following kelotomy in Dog 3 , $3 \times 2 \mathrm{~cm}$ in Dog 4, $2.5 \times 2.5 \mathrm{~cm}$ in Dog 5 and $2 \times 2 \mathrm{~cm}$ following kelotomy in Dog 6. The surgical technique adopted for inlay placement of the graft was very effective for covering the defect and correction of hernia.

\section{Evaluation of study}

\section{Respiration rate}

Respiration rate (per min) was $22.00 \pm 0.73$ on day zero, $22.33 \pm 0.33$ on $7^{\text {th }}$ day, $21.67 \pm$ 0.62 on $14^{\text {th }}$ day, $21.00 \pm 0.68$ on $30^{\text {th }}$ day and $21.00 \pm 0.68$ on $60^{\text {th }}$ day of the observation period. The variations observed were within the normal physiological range.

\section{Pulse rate}

Pulse rate (per min) was $93.17 \pm 0.79$ on day zero, $98.50 \pm 0.50$ on $7^{\text {th }}$ day, $96.00 \pm 0.73$ on $14^{\text {th }}$ day, $95.50 \pm 0.81$ on $30^{\text {th }}$ day and $93.33 \pm$ 0.49 on $60^{\text {th }}$ day of the observation period. The variations observed were within the normal physiological range. Significant difference was observed on $7^{\text {th }}$ and $30^{\text {th }}$ day of the observation period.

\section{Rectal temperature}

Rectal temperature $\left({ }^{\circ} \mathrm{F}\right)$ was $101.8 \pm 0.89$ on day zero, $102.03 \pm 0.21$ on $7^{\text {th }}$ day, $101.87 \pm$ 0.84 on $14^{\text {th }}$ day, $101.87 \pm 0.42$ on $30^{\text {th }}$ day and $101.90 \pm 0.45$ on $60^{\text {th }}$ day of the observation period. The variations were within the normal physiological range

\section{Colour of mucous membrane}

Colour of mucous membrane was pale roseate in all the animals during the entire observation of 60 days.

\section{Haematological parameters}

\section{Total erythrocyte count}

The total red blood cell count $(10 \%$ cumm) was $7.07 \pm 0.67$ on day zero, $5.93 \pm 0.05$ on $7^{\text {th }}$ day, $6.50 \pm 0.05$ on $14^{\text {th }}$ day, $6.92 \pm 0.05$ on $30^{\text {th }}$ day and $6.95 \pm 0.06$ on $60^{\text {th }}$ day postoperative. The variations observed were within the normal range. Significant 
difference was noticed on $7^{\text {th }}$ day and $14^{\text {th }}$ day of the observation period.

\section{Total leucocyte count}

The total leucocyte count $\left(10^{3} / \mathrm{cumm}\right)$ was $9.82 \pm 104.62$ on day zero, $15.40 \pm 81.65$ on $7^{\text {th }}$ day, $13.63 \pm 314.55$ on $14^{\text {th }}$ day, $10.05 \pm$ 91.19 on $30^{\text {th }}$ day and $9.97 \pm 80.28$ on $60^{\text {th }}$ day post-operative. The variations observed were within the normal range. Significant difference was noticed on $7^{\text {th }}$ day and $14^{\text {th }}$ day of the observation period.

\section{Differential leucocyte count}

\section{Neutrophils}

The neutrophil count $(\%)$ was $71.50 \pm 0.43$ on day zero, $91.00 \pm 0.37$ on $7^{\text {th }}$ day, $76.50 \pm$ 0.56 on $14^{\text {th }}$ day, $71.00 \pm 0.37$ on $30^{\text {th }}$ day and $70.33 \pm 0.21$ on $60^{\text {th }}$ day post-operative. The variations observed were within the normal range. Significant difference was noticed on $7^{\text {th }}$ day and $14^{\text {th }}$ day of the observation period.

\section{Lymphocytes}

The lymphocyte count (\%) was $26.17 \pm$ 0.31 on day zero, $7.83 \pm 0.31$ on $7^{\text {th }}$ day, 22.00 \pm 0.37 on $14^{\text {th }}$ day, $27.00 \pm 0.37$ on $30^{\text {th }}$ day and $28.00 \pm 0.37$ on $60^{\text {th }}$ day post-operative. The variations observed were within the normal range.

\section{Eosinophils}

The eosinophil count $(\%)$ was $2.33 \pm 0.21$ on day zero, $1.17 \pm 0.17$ on $7^{\text {th }}$ day, $1.50 \pm 0.22$ on $14^{\text {th }}$ day, $2.00 \pm 0.26$ and $1.67 \pm 0.21$ on $60^{\text {th }}$ day post-operative.

The variations observed were within the normal range. Significant difference was observed on day 7 and 14 of the observation period.

\section{Volume of packed red cells}

Volume of packed red cells (\%) was $43.33 \pm$ 0.49 on day zero, $39.00 \pm 0.37$ on $7^{\text {th }}$ day, $42.67 \pm 0.49$ on $14^{\text {th }}$ day, $43.33 \pm 0.42$ on $30^{\text {th }}$ day and $43.17 \pm 0.54$ on $60^{\text {th }}$ day postoperative Significant difference was noticed on $7^{\text {th }}$ day and $14^{\text {th }}$ day of the observation period.

\section{Haemoglobin concentration}

Haemoglobin concentration $(\mathrm{g} / \mathrm{dl})$ was 15.05 \pm 0.08 on day zero, $12.58 \pm 0.24$ on $7^{\text {th }}$ day, $13.97 \pm 0.07$ on $14^{\text {th }}$ day, $15.08 \pm 0.06$ on $30^{\text {th }}$ day and $15.02 \pm 0.02$ on $60^{\text {th }}$ day postoperative. The variations observed were within the normal range. Significant difference was noticed on $7^{\text {th }}$ day and $14^{\text {th }}$ day of the observation period. The variations observed were within the normal range. Significant difference was noticed on $7^{\text {th }}$ day of the observation period.

\section{Erythrocyte sedimentation rate}

Erythrocyte sedimentation rate $(\mathrm{mm} / \mathrm{h})$ was $7.67 \pm 0.21$ on day zero, $9.67 \pm 0.33$ on $7^{\text {th }}$ day, $8.33 \pm 0.21$ on $14^{\text {th }}$ day, $7.67 \pm 0.21$ on $30^{\text {th }}$ day and $7.50 \pm 0.24$ on $60^{\text {th }}$ day postoperative. The variations observed were within the normal range. Significant difference was noticed on $7^{\text {th }}$ day of the observation period.

\section{Biochemical parameters}

\section{Blood glucose}

Blood glucose $(\mathrm{mg} / \mathrm{dl})$ was $82.67 \pm 0.62$ on day zero, $83.83 \pm 0.48$ on $7^{\text {th }}$ day, $85.33 \pm$ 0.42 on $14^{\text {th }}$ day, $88.00 \pm 0.68$ and $86.83 \pm$ 0.65 on $60^{\text {th }}$ day post-operative.

The variations observed were within the normal range. Significant difference was 
noticed on $14^{\text {th }}, 30^{\text {th }}$ and $60^{\text {th }}$ day of the observation period.

\section{Serum total proteins}

Serum total proteins $(\mathrm{g} / \mathrm{L})$ was $6.47 \pm 0.14$ on day zero, $6.12 \pm 0.07$ on $7^{\text {th }}$ day, $6.62 \pm 0.15$ on $14^{\text {th }}$ day, $6.45 \pm 0.09$ on $30^{\text {th }}$ day and 6.50 \pm 0.09 on $60^{\text {th }}$ day post-operative.

The variations observed were within the normal range. Significant difference was observed on $7^{\text {th }}$ day of the observation period.

\section{C-reactive protein}

C-reactive protein $(\mathrm{mg} / \mathrm{L})$ was $4.12 \pm 0.22$ on day zero, $8.67 \pm 0.08$ on $7^{\text {th }}$ day, $5.65 \pm 0.09$ on $14^{\text {th }}$ day, $4.32 \pm 0.08$ and $4.23 \pm 0.07$ on $60^{\text {th }}$ day post-operative. Significant difference was noticed on $7^{\text {th }}$ day and $14^{\text {th }}$ day of the observation period.

\section{Tissue changes}

The tissue changes and the complications observed at the surgical site were recorded (Plate 5 to Plate 11).

Plate.1 Preparation of the graft

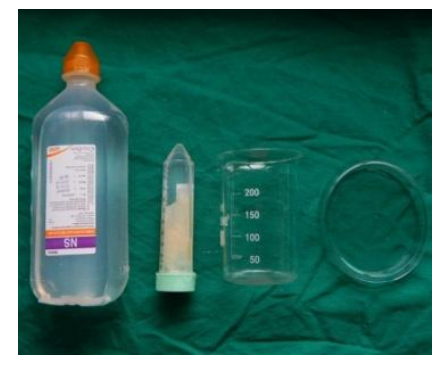

Items for preparation of graft before implantation

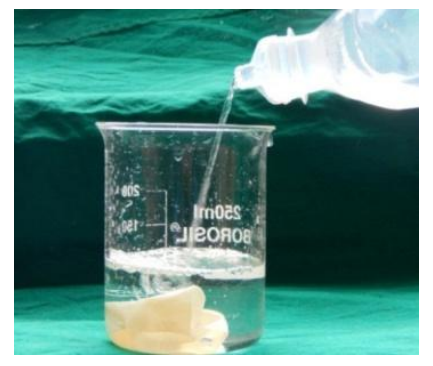

Rinsing of graft with normal saline

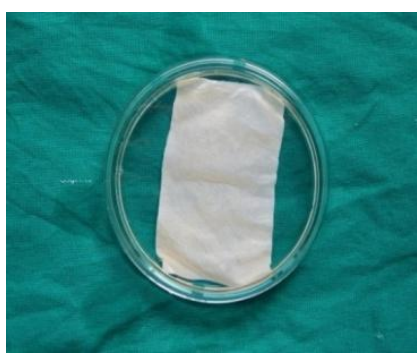

Decellularised bovine pericardium prepared for implantation

Plate.2 Preparation of site

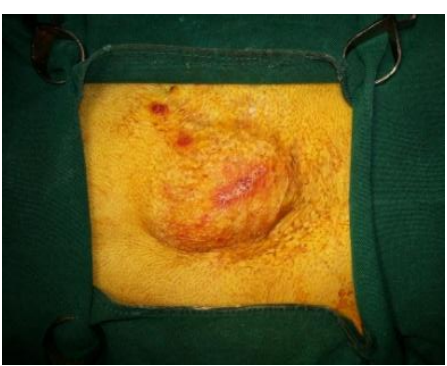

Site of surgery after aseptic preparation and application of drapes 
Plate.3 Surgical implantation of Bovine Pericardium

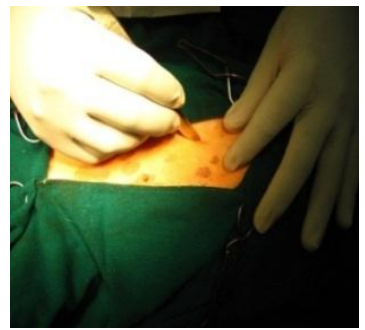

Skin incision

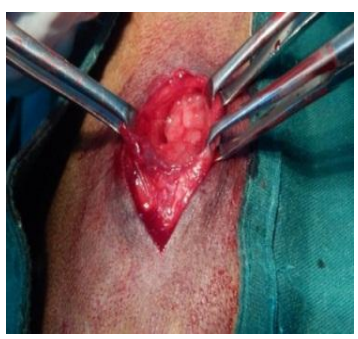

Exposing the hernial ring

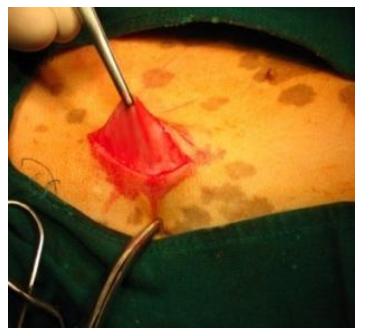

Exposing the hernial sac

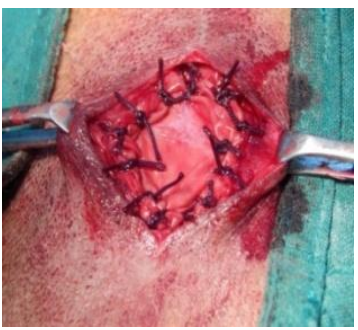

Decellularised bovine pericardium fixed as inlay graft

Plate.4 Dog applied with multi-tailea avuvinnaı vanuage after surgery

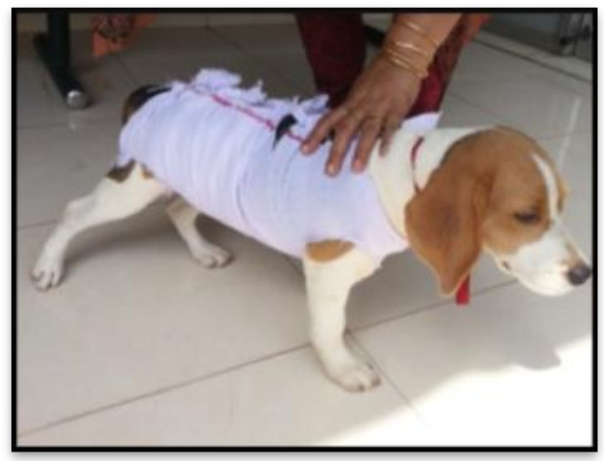

Plate.5 Tissue changes in Dog 1
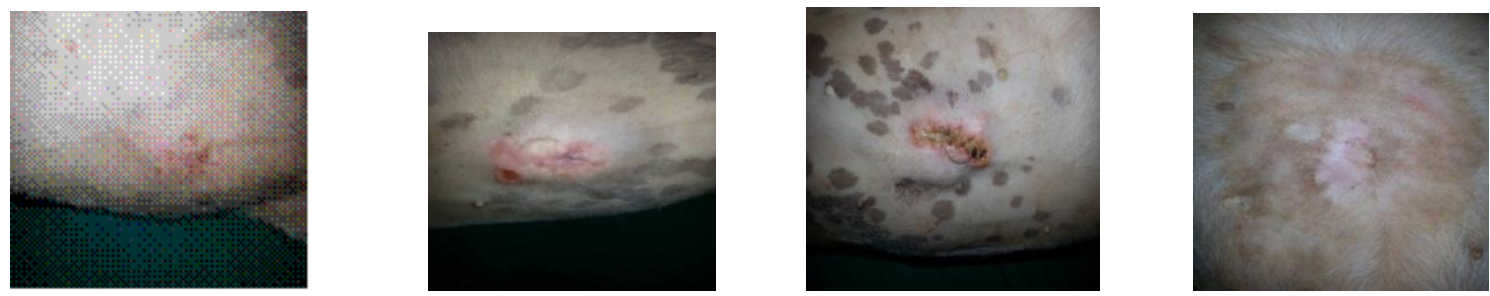
Plate.6 Tissue changes in Dog 2
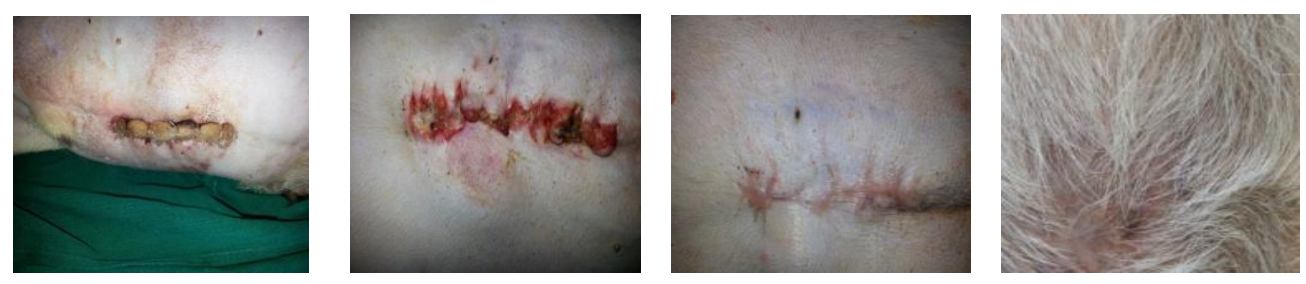

Plate.7 Tissue changes in Dog 3
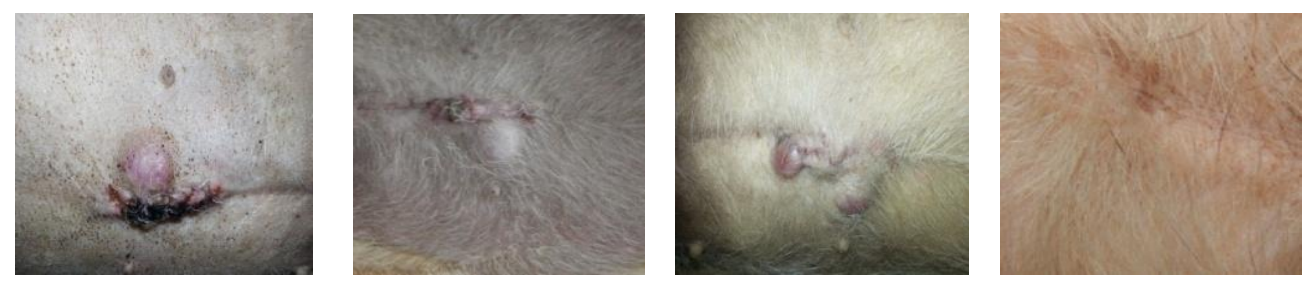

Plate.8 Tissue changes in Dog 4
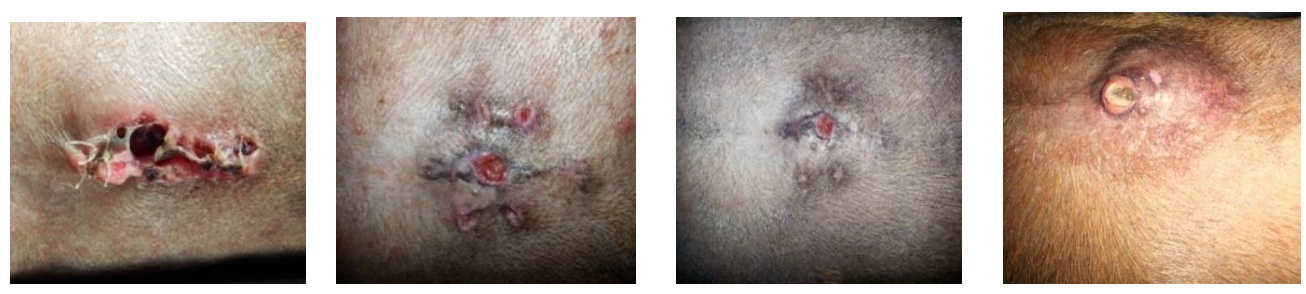

Plate.9 Tissue changes in Dog 5
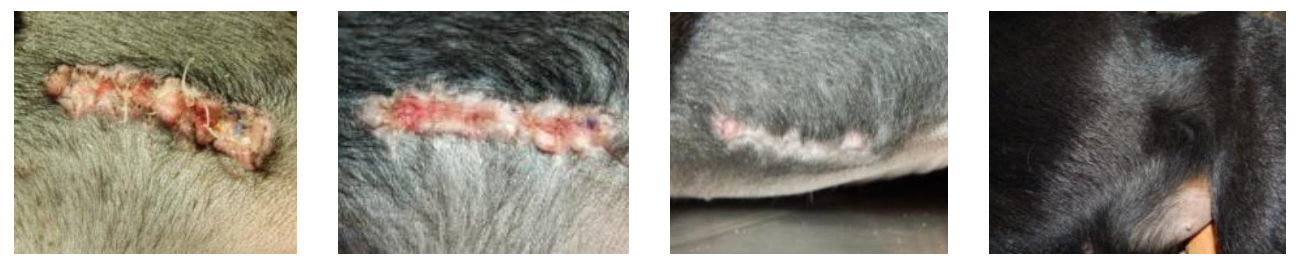

Plate.10 Tissue changes in Dog 6
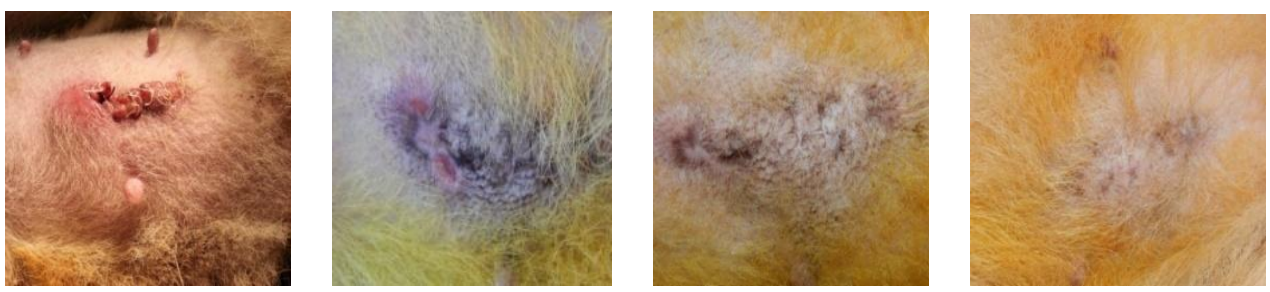


\section{Plate.11 Complications \\ Delayed wound healing \\ Dog2}

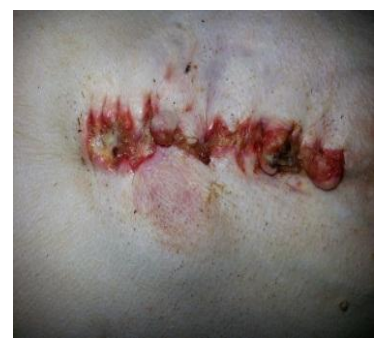

Day 14

Seroma formation

$\operatorname{Dog} 1$

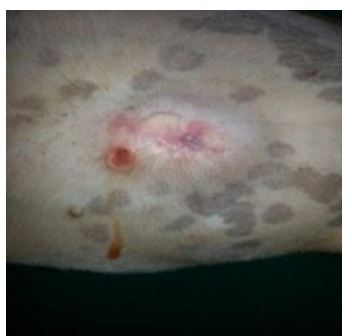

Day 14
$\operatorname{Dog} 3$

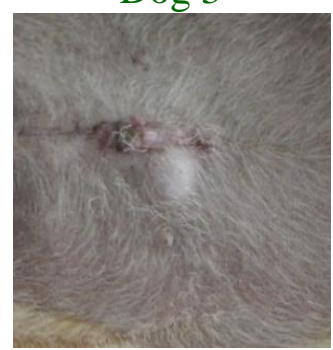

Day 14

Recurrence of Hernia

Dog 4

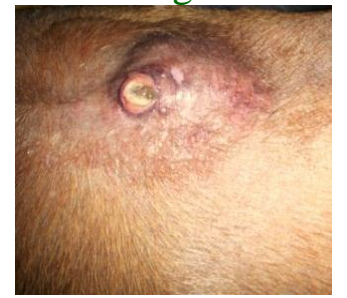

Day 60

The surgical repair of the hernia in all the six dogs was performed by hernioplasty using decellularised bovine pericardium as the graft material. The surgical correction of hernia can be done by herniorrhaphy or hernioplasty. Herniorrhaphy often fails to bring about a tension free correction especially in the case of large defect and also in those cases where there is possibility of developing tension at the surgical site as in the case of ventral hernia where the weight of the whole body is exerted. In such cases it is always advised to go for hernioplasty. Luijendijk et al., (2000) concluded from his observation that mesh repair was found to be superior over the simple suture repair despite the size of hernia. Singh et al., (2011) opined that closure of large defects by herniorrhaphy could lead to undue tension at the suture site and thereby could lead to the recurrence of the condition, so in such cases hernioplasty is recommended.

Decellularised bovine pericardium was utilized for performing hernioplasty. The application of bovine pericardium for the 
correction of the hernia could be justified by the observations made by James et al., (1991), Zardo et al., (2011) and Suvaneeth (2013). In an experimental study in rabbits James et al., (1991) concluded that implantation of bovine pericardium leads to the development of a strong, stable fibrous tissue replacement that helped in covering the defect. Zardo et al., (2011) opined that bovine pericardium could be a viable alternative for the correction of defects in the diaphragm. Suvaneeth (2013) reported that decellularised bovine pericardium could successfully induce regeneration following the implantation in surgically created hernia in rats.

The defect was corrected by placing the bovine pericardium as an inlay graft which was trimmed to the size of the defect. The graft was placed over the defect and it was sutured to the margins of the defect using polyglactin 910 in simple interrupted pattern. Similar procedure was also done by Gangwar et al., (2003) and Gangwar et al., (2012) in ventral hernia in goat wherein hernioplasty was performed using acellular dermal matrix and bovine aortic graft. The graft was placed over the defect as inlay graft and sutured to the edges of the defect in simple continuous pattern using silk. Devarathnum et al., (2012) also used the similar technique for the correction of ventral hernia in Holstein Friesian calves where he used acellular aortic grafts as an inlay graft.

When the graft is placed as an inlay graft the most important complication that can develop is the formation of adhesion with the underlying bowel. Decurtins and Buchman (1982) concluded from their experimental studies in $\operatorname{dog}$ s that the use of bovine pericardium caused minimal adhesion with the underlying bowel, when compared with the application of Mersilene meshes.

When a bioscaffoldis used one of the factor that concerns is their ability to maintain the mechanical strength following implantation. According to Gangwar et al., (2003), the acellular bioscafffolds would maintain their mechanical properties upon implantation and they promoted the remodeling by neovascularisation and recellularisation. They also opined that collagen being a universal biological molecule it would exhibit very slight difference between species and produce only minimal antigenic response. The bioscaffold application took the spot light over the synthetic meshes mainly because of their ability to resist infection. Upon implantation they promote neovascularisation thereby helping to prevent infection. Rodgers et al., (1981) concluded that use of synthetic meshes have the major disadvantage that they are very much susceptible to infection. Because of this susceptibility to infection, their application in contaminated fields is always questionable.

Holton et al., (2005) explained the importance of using these bioscaffolds over synthetic meshes and autologous grafts. When synthetic meshes are used in contaminated fields there is greater possibility for the mesh failure. This is because they lack an endogenous vascular network and thereby they are incapable of cleaning up the bacterial load. Autologous grafts when used to cover large body wall defects it cause the major disadvantage that it produce significant donor site morbidity. These could be overcome by the application of bioscaffolds (Holton et al., 2005; Butler, 2006).

The important characteristics that the bioscaffolds possess which allow its application for the repair of body wall defects were mentioned by D'Ambra et al., (2012). The bioscaffolds have ability to resist infection and remodeled into host tissue with the characteristics similar to the host tissue. These characteristics facilitated its use in those fields where the applications of prosthetic meshes were compromised. 


\section{Evaluation of study}

\section{Physiological parameters}

Physiological parameters like respiration rate, pulse rate and rectal temperature showed variations within the normal range during the post-operative observation period. A significant difference in the pulse rate was noticed on the $7^{\text {th }}$ and $30^{\text {th }}$ post-operative day.

\section{Haematological parameters}

The Total erythrocyte count, Haemoglobin concentration and Volume of packed red cells showed variations during the post-operative observation period but they were in the normal range. A significant decrease in the total erythrocyte count, haemoglobin concentration and volume of packed red cells were observed on $7^{\text {th }}$ day and $14^{\text {th }}$ day postoperative. Although a decrease in the levels were noticed on $14^{\text {th }}$ day post-operative when compared to the pre-operative value, the observations showed an increase in value when compared to the $7^{\text {th }}$ day post-operative which were suggestive that the animal was regaining the normal pre-operative status. By $30^{\text {th }}$ day post-operative all the animals attained their normal pre-operative status. The decrease in the level of the parameters noticed in the first week might be due to the stress from surgery. Most of the animals were offfed during the immediate period of surgery which might have deteriorated the general health status of the animals. Once the animals have recovered from the surgical stress they improved to normal appetite that led to the increase in the counts to pre-operative levels.

The decrease in the haemoglobin concentration that was observed during the post-operative period was in accordance with the observation that was made by Senthilkumar, (2000). A decrease in the haemoglobin concentration was observed following hernioplasty using processed oesophageal allografts in pigs. He suggested that the stress that was created by the surgery might have been the cause for the decrease in haemoglobin level that was noted during the immediate post-operative days.

Erythrocyte sedimentation rate showed a significant increase during the first postoperative observation on $7^{\text {th }}$ day. The significant increase that was observed might have been due to the inflammatory response that was seen during the immediate postoperative period.

The cellular reactions which occur as a result of the healing following surgery might have been the possible reason which would have led to the variations observed in the haemogram (Parker, 1985).

The total leucocyte count was elevated during the first week post-operative. Zardo et al., (2011) made a similar observation in human patients who had undergone diaphragmatic repair with bovine pericardium where elevation in the level of the total leucocyte count was noticed between day 4 and day $7^{\text {th }}$ post-operative. The total leucocyte count returned to the pre-operative period $30^{\text {th }}$ day post-operative. The neutrophil count was also seen to increase with the total leucocyte count and the neutrophil count returned to the preoperative level by $30^{\text {th }}$ post-operative day. The sudden increase in the total leucocyte count with increase in neutrophil might be due to the surgical procedure and subsequent inflammatory process. The reduction in the levels to the normal range suggested that no infection systemically following the implantation of the bovine pericardial graft.

\section{Biochemical parameters}

Blood glucose, serum total proteins and Creactive proteins were the biochemical 
parameters that were monitored during the observation period. C-reactive proteins showed a significant increase in level during the $7^{\text {th }}$ day of the post-operative period. The increase in the level of C-reactive protein was in accordance with the observation of Zardo et al., (2011), wherein elevated C-reactive protein values were noticed between day 4 and day 7 of the post-operative period.

The serum total proteins showed a slight decrease in level during the $7^{\text {th }}$ day postoperative. The decrease in level might be due to the stress from surgery.

Blood glucose levels were maintained within the normal range during the entire observation period. A significant difference was observed on $14^{\text {th }}, 30^{\text {th }}$ and $60^{\text {th }}$ day post-operative. The blood glucose level depends mainly on the feeding time of the animal and since all the values were well within the normal range it was suggestive the animals were not suffering from diabetes.

\section{Acknowledgement}

The authors would like to acknowledge the cancellor and vice chancellor of Kerala Veterinary and Animal Sciences University, Dean of College of Veterinary and Animal Sciences Mannuthy, Head of Department Veterinary Surgery and Radiology, College Of Veterinary and Animal Sciences, Mannuthy, Thrissur and the scientists of Sree Chitra Tirunal Institute of Medical Sciences and Technology, Thiruvananthapuram for providing facilities for the successful completion of the work.

\section{References}

Butler, C. E. 2006. The role of bioprosthetics in abdominal wall reconstruction. Clin.Plast. Surg.33: 199-211.

D’Ambra, L., Berti, S., Feleppa, C.,
Magistrelli, P., Bonfante, P. and Falco, E. 2012. Use of bovine pericardium graft for abdominal wall reconstruction in contaminated fields.Wld. J. Gastrointest. Surg.4: 171-176.

Decurtins, M. and Buchmann, P. 1982. Bovine pericardium - a new graft material for hernia repair.Res. Exp. Med. (Berl).180:11-14.

Devarathnum, J., Sharma, A. K., Gangwar, A. K., Kumar, V., Kumar, N., Singh, H., Kaarthick, D. T., Pawde, A. M. and Maiti, S. K. 2012. Acellular aortic grafts for the reconstruction of umbilical hernia in Holstein-Friesian calves.Vet. Pract.13: 307-308.

Gangwar, A. K., Kumar, V., Devarathnum, J., Kumar, N., Sharma, A. K., Singh, H. and Kaarthick, D. T. 2012. Acellular aortic matrix for the repair of large ventral hernia in a buck.Vet. Pract.13: 293-294.

Gangwar, A. K., Sharma, A. K., Kumar, N. and Kumar, N. 2003. Surgical management of ventral hernia with glutaraldehyde treated acellular dermal grafts in a goat. Vet. Pract.4: 25-26.

Gangwar, A. K., Sharma, A. K., Kumar, N., Gupta, O. P., Devi, S. and Singh, H. 2003. Acellular grafts for reconstructive surgery in animals: a review. Vet. Pract.4: 124-129.

Holton, L. H., Kim, D., Silverman, R. P., Rodriguez, E. D., Singh, N. and Goldberg, N.H. 2005. Human acellular dermal matrix for repair of abdominal wall defects: review of clinical experience and experimental data. J. Long Term Eff. Med. Implants.15: 547558.

James, N.L., Poole-Warren, L. A., Schindhelm, K., Milthorpe, B. K., Mitchell, R. M., Mitchell, R. E. and Howlett, C. R. 1991. Comparative evaluation of treated bovine pericardium as a xenograft for hernia 
repair.Biomaterials.12: 801-809.

Luijendijk, R.W., Hop, W. C., Van den Tol, M. P., De Lange, D. C., Braaksma, M. M., Ijzermans, J. N., Boelhouwer, R. U., De Vries, B. C., Salu, M. K., Wereldsma, J. C., Bruijninckx, C. M. andJeekel, J. 2000. A comparison of suture repair with mesh repair for incisional hernia. N. Engl. J. Med. 343: 392-398.

Parker, H. R. 1985.Post-operative management.In. Gourley, I. M. and Vasseur, P. B. (ed.), General small animal surgery. Lippincott. Philadelphia, pp. 49-63.

Rodgers, B. M., Maher, J. W. and Talbert, J. L. 1981.The use of preserved human dura for the closure of abdominal wall and diaphragmatic defects.Ann. Surg. 193: 606-610.

Senthilkumar, S. 2000. Processed oesophageal allografts for hernioplasty in pigs.M.V.Sc Thesis, Kerala
Agricultural University, Thrissur, 81p. Singh, K., Mahajan, S. K., Sangwan, V., Kumar, A., Gopinathan, A. and Saini, N. S. 2011. Ventral abdominal hernioplasty using polypropylene mesh in a cow.. Indian J. Vet. Surg.32: 71.

Suvaneeth, P. 2013. Comparative healing responses of differentially processed bovine pericardium in rat abdominal regeneration model.M.V.Sc. Thesis. Kerala Veterinary and Animal Sciences University, Pookode, 71p.

Thilagar, S., Tan, S. Y. and Lob, P. K. 2006.Left paracostal hernia in a pup.Indian J. Vet. Surg. 27: 139-140.

Zardo, P., Zhang, R., Wiegmann, B., Haverich, A.andFischer, S. 2011. Biological materials for diaphragmatic repair: initial experiences with the PeriGuard Repair Patch. Thorac.Cardiovasc. Surg. 59: 40-44.

\section{How to cite this article:}

Nijin Jos, B. M., C. B. Devanand, K. D. John Martin and Syam K. Venugopal. 2020. Decellularised Bovine Pericardium for Hernioplasty in Dogs. Int.J.Curr.Microbiol.App.Sci. 9(08): 16-28. doi: https://doi.org/10.20546/ijcmas.2020.908.003 